\title{
Youth's Trust in Online News Media About The Corona Virus Issues
}

\author{
Andini Nur Bahri \\ Dosen UIN Sumatera Utara \\ Email: andininurbahri@uinsu.ac.id
}

\begin{abstract}
News and information about the corona virus has become the topic most often consumed by the public lately despite the declining public trust in the media both traditional media and online media. It also affects the younger generation in consuming media and trusting the credibility of a media. This study aims to determine the trust of students who have studied science related to the media, namely students of Islamic communication and broadcasting UINSU on online news websites about the corona virus and how is the relationship between the selection of online news website with trust in media. This study uses descriptive correlational methods with as many respondents 228 people. This research found that most of the students chose national online news websites in getting news about corona and there was no significant relationship between online news site selection and students' belief that the online news websites published accurate facts about corona virus.
\end{abstract}

Keywords: Trust; News Media; Website

\section{INTRODUCTION}

The Covid-19's topic in Indonesia is developing very rapidly. Because the Corona outbreak is a world issue and is not only in Indonesia, the subject has become a broad conversation. This Corona conversation has an impact and is related on the discussion of many different topics in terms of the world's social, political, and cultural aspects. This has implications for how the media brings their perspectives in preaching the Corona topic. But once again it needs to be emphasized that if the conversation cannot be monitored for its truth, hoaxes will actually be very likely to become "main players" in the conversation as mentioned in the previous analysis.

When looking at the Corona conversation data from various sources, it is increasingly clear that the topic of Corona is more widely discussed on online news websites by 37 percent, followed by Facebook (43 percent) and Youtube (12 Percent). ${ }^{1}$ Data development from the beginning of March to April, has showed that what previously appeared more on social media is now appearing more on the website. It should be noted here that news access to the website is actually a positive because most also access official or trusted news portals. Attention is

\footnotetext{
${ }^{1}$ Lestari Nurhajati Rudi Sukandar, Perbincangan isu corona covid 19 pada Media Daring dan Media Sosial.Lembaga Penelitian Pengabdian, Publikasi Masyarakat.P.14
} 
given not only to hoaxes, but also news content which is an important aspect in the discussion of this topic. The media with their various interests can lead opinions or sentiments to the public about the Corona issue and its relation to political interests and so on.

In the midst of the turmoil that engulfed the world with the emergence of the coronavirus, there are also lies or hoaxes being spread by irresponsible parties. Various hoaxes that appear and add unrest in the community. News that cannot be accounted for the truth, besides confusing the community, also has the potential to cause chaos if left unchecked. The secretary at the Secretariat of the Directorate General of Disease Prevention and Control (P2P) Ministry of Health confirmed that up until now, there is still false information that is spread about the coronavirus. The amount of misinformation in the community is one of the causes of increased public anxiety over the coronavirus. Dissemination of misinformation only worsens the corona virus problem ${ }^{2}$. At least until February 4, 2020, the Ministry of Communication and Information (Kemkominfo) found that there were 60 cases of misinformation circulating on social media and messaging applications about the 2019-nCoV or Corona virus. This number has gone up from the previous four days, of 36 misleading articles.

Freedom of press was born from the spirit of reform with the issuance of the Press Law No. 40 of 1999, becoming the foundation of democracy in Indonesia. Additionally, media experiencing significant growth. In the press data Press Council, which is estimated to have 47,000 media in Indonesia. Among this number, 43,300 are online media. ${ }^{3}$

The press business as a business of trust, must lay the foundation in the public interest. A credible press will guarantee the loyalty of the audience. To build and maintain its credibility, the press is demanded to be able to firmly carry out its professional duties, namely conveying the truth for the public interest. Therefore, the press must be independent in every report and refer to the public interest. How does the public put their trust in the mainstream media press, in comparison to alternatives platforms, including social media. Journalists in online media in general, are expected to be present as people who have the ability to multi-task, starting from verifying information, writing news, editing it, taking photos and videos. In addition to their multi-tasking capabilities, journalists are also required to produce news with a specific quota every day and produce clickbait-friendly news with internet search engines. While trust has been viewed as an essential variable in media consumption, concerns have been made about the decline of trust from public sectors. Much to the anxiety of media professionals,

\footnotetext{
${ }^{2}$ https://tirto.id/kerja-berat-kemenkes-menangkal-hoaks-virus-corona-ev68

${ }^{3}$ Dewan Pers, Data Pers 2014, Jakarta 2015, dan Dewan Pers, Data Pers 2015, Jakarta 2016.
} 
trust in the media remains lower than the public's trust in most other institutions. ${ }^{4}$

And now society is facing a media crisis. It is that people are consuming news from media they do not trust. While prior sociological research shows that the trust parallel action toward the trusted source, several media studies say otherwise. ${ }^{5}$ Gallup's polling results on trust and use of new media find that use of the Internet is much lower than traditional news sources, and so is trust in the Internet. But another poll published in 2010 on traditional media, finds that young people ages 18 to 29 read newspapers the least and use television as their main source even though they claim to have more trust in newspapers than TV.

Trust might not be a strong variable for the use of news media among university students after all. Although these students still use a source for news and information despite their skepticism, news consumption among the younger audience remains low or worse, dropping over the years. ${ }^{6}$ This study aims to describe the confidence in the online news media of university students about the corona virus, the extent of the relationship between their choice of online news websites, and the level of trust about the corona virus.

\section{LITERATURE REVIEW}

\section{A. Trust in Media}

Trust is a hope for others that someone's beliefs will not take action for profit alone. Trust is earned within the relationship of a trustee and trustor. Where the trustor is the party that is trusted, and the trustee is the party that decides to believe the trustor. Broader public perspective, distrust of mass media can damage the ability of the media to inform the public, and consequently consumers may not be aware of other issues or alternative perspectives outside their personal networks. Trust according to Mayer, Davis, and Schoorman (1995) is formed from 3 aspects, namely ability, benevolence, and integrity. ${ }^{7}$ One of the reasons of distrust come from hoax news. Hoaxes are one of the medias contents, deliberately created by media institutions or companies, made to influence perceptions about how one's program views the real world people's thoughts and behavior. ${ }^{8}$

Trust in the media might be based on a person's belief in the professionalism of journalistic practice. Media professionals often argue that without audiences' trust,

\footnotetext{
${ }^{4}$ Cook, T,E., \& Gronke, W. (2001). The dimensions of institutional trust. Paper presented at the annual meeting of the Midwest Political Science Association, Chicago, IL. Retrieved April 5, 2011 from http://www.reed.edu/ gronkep/papers.html

${ }^{5}$ Keele, L. (2007). Social capital and the dynamics of trust in government. American Journal of Political Science, 51 (2), 241-254.

${ }^{6}$ Lee, Soo Hui, "Does Trust Really Matter? A Quantitative Study of College Students' Trust and Use of News Media" (2011). Theses from the College of Journalism and Mass Communications. 15. https://digitalcommons.unl.edu/journalismdiss/15

${ }^{7}$ Mayer, R.C., Davis, J.H., \&Schoorman, F.D.(1995). An integrative model of organicational trust. Academy of management review, 20(3), 709-734

${ }^{8}$ Tamburaka. (2013). Literasi media. Jakarta : PT Raja Grafindo Persada.
} 
they may be less committed to the journalistic norms. The more they feel trusted, the stronger the identification of journalists with professional norms relating to trust, such as remaining neutral, getting the facts right, and telling both sides of the story. With that being said, trust in the media not only acts as a lubricant that enhances the interactions with the users, it also helps maintain professionalism in journalists. Recently, Tsfati and Ariely's (2014) analysis of World Values Survey data from 44 countries indicated that trust in the news media is positively correlated with political interest, interpersonal trust, and exposure to television news and newspapers. Education level and online news exposure were negatively correlated.

\section{B. Multiple Factor Model of Trust in News Media}

Kohring believe that the assesment of media user when they consume news based on four dimensions as following: ${ }^{9}$

a. Trust in the Selectivity of Topics

The first dimension of trust is associated with the selection of reported topics. The recipients trust that the news media will focus on those topics and events that are relevant to them.

b. Trust in the Selectivity of Facts

This dimension concerns the selection of facts or background information pertaining to a topic that has already been selected. It is the way in which an event is contextualized that is relevant to this dimension

c. Trust in the Accuracy of Depictions

This dimension includes trust in verifiable and approvable accuracy of depicted facts. Although observations are highly selective and their classification into "right" or "wrong" is not objectively assignable, a number of observations allow a stan- dardized classification into "right" and "wrong" and are therefore verifiable.

d. Trust in Journalistic Assessment.

The selection of an event or information already represents an evaluation. Additionally, there are explicitly emphasized assessments, especially in commentary structure. These offer advice as well as assessments of and appeals for action.

\section{Youth's News Source}

Young people under the age of 24 who are born between 1995 and 2012 are called digital natives ${ }^{10}$. The characteristics of this young generation who are fluent with technology spend an average of 9 hours per day with their cellphones pragmatic, alert, prioritizing togetherness, communicating with images, and

\footnotetext{
${ }^{9}$ Kohring, M., \& Matthes, J. (2007). Trust in news media: Development and validation of a multidimensional scale. Communication Research, 34(2), 231-252.

${ }^{10}$ Prensky, M. (2001, October). Digital Natives, Digital Immigrants. On The Horizon, 9(5), pp. 1-6.
} 
11

spreading collective awareness. They want attention to the different information needs of each individual, the opportunity to provide direct feedback on what is received, the active collaboration techniques of the parties involved, and to consume information that is easily accessed and understood. ${ }^{12}$

In recent years, social media has even become one of the largest 13

distributors for news and has become a key space for sharing and recommending news. The main reason being that users see it as a trend to move from traditional 14

media to digital media. $45 \%$ of young people access news through social media and $97 \%$ of these users use their smartphones as their main source of media. They choose news through social media because it can be accessed directly and easily, with a variety of news being offered, a wider choice of perspectives, the freedom to choose, and easy access in finding breaking news . In a research done by Metzger et al. (2003) on students' perception towards the information credibility of the web use shows that students tend to depend on the web for information rather than seeking information from the library. In fact the research showed that students depended on the world wide web for information when they were assigned to do research in college. However it is said that web-based information differed from the traditional channels as news medium of newspapers was found to have balance, honesty and currency dimensions. ${ }^{15}$

The research of Sharon conducted a survey of the students' preference of news media and the majority of the students chose to seek out online news because the traditional media in Malaysia fails to provide sufficient information and is perceived to have more censorship or legal restrictions than online news websites. Due to fewer such restrictions, alternative news websites are also deemed more fair and objective in their news articles; additionally they also provide more comprehensive coverage - particularly for controversial issuescompared to the mainstream news media. Students also believe that alternative news websites present different viewpoints, are more critical, have more in-depth

${ }^{11}$ Daugherty, T., \& Hoffman, E. (2014). eWOM and The Importance of Capturing Consumer Attention Within Social Media. Journal of Marketing Communication, 20(1-2), 82-102. doi:10.1080/13527266.2013.797764

${ }^{12}$ Swanzen, R. (2018). Facing The Generation Chasm: The Parenting and Teaching of Generations Y and Z. International Journal of Child, Youth and Family Studies, 9(2), 125-150. doi:10.18357/ijcyfs92201818216

${ }^{13}$ Krumsvik, A. H. (2018). Redefining User Involvement in Digital News Media. Journalism Practice, 12(1), 19-31. doi:10.1080/17512786.2017.1279025

${ }^{14}$ Ksiazek, T. B., Malthouse, E. C., \& Webster, J. G. (2010). News-seekers and Avoiders: Exploring Patterns of Total News Consumption Across Media and the Relationship to Civic Participation. Journal of Broadcasting \& Electronic Media, 54(4), 551-568. doi:10.1080/08838151.2010.519808

${ }^{15}$ Metzger, M.J., Flanagin, A.J., \& Zwarunb, L.(2003). College student web use, perception of information credibility and verification behaviour. Computer and Education. 41 :271-290. 
analysis and online writers are relatively free from interference. ${ }^{16}$

\section{RESEARCH METHOD}

This research uses correlational quantitative methods. Population is a generalization area that consists of objects / subjects that have certain qualities and characteristics determined by researchers to be studied and then drawn conclusions. ${ }^{17}$ Based on this information, the population in this study were students of the North Sumatra State Islamic University who had formally studied media related science. The Department of Communication and Broadcasting is one of the departments that studies media. Based on data from the Ministry of Research, Technology and Higher Education (Kemenristekdikti), the number of active students in 2019/2020 is 529 people.

The sample is part of the number and characteristics possessed by the population. What is learned from the sample, the conclusion can also apply to the population. For this reason, according to Sugiyono (2016) samples taken from the population must be truly presentative. Determination of sample size in this study is based on the Slovin formula in order to get a more certain sample or approach the existing population. As follows:

$$
n=\frac{N}{1+N e 2}
$$

$\mathrm{n}=$ Sample size,

$\mathrm{N}=$ Population size,

$\mathrm{e}=$ Error level tolerated The results of calculations in determining the minimum sample with an average population of UINSU students, by setting a precision of $5 \%(0.05)$ are as follows.

$$
\begin{aligned}
& n=\frac{529}{1+529(0,05)^{2}} \\
& n=227,77
\end{aligned}
$$

Based on these calculations, the number of samples in this study was 227.77 or rounded up to 228 people. The sampling technique is purposive sampling, according to Sugiyono that: "purposive sampling is a technique for sampling data sources with certain considerations. Determination of the sample in this study using non-probability sampling is sampling that does not provide equal opportunities for representing the population to be selected as research samples, or non-random sampling.

\footnotetext{
${ }^{16}$ sharon wilson, pauline leong, $\mathrm{dr}$ carmen nge \& dr ngerng miang hong. Trust and credibility of urban youth on online news media. Jurnal Komunikasi Malaysian Journal of Communication Jilid 27(2): $97-120$

${ }^{17}$ Sugiyono, (2016), Metode Penelitian Kuantitatif Kualitatif dan R\&D, alfabeta, Jakarta.
} 
The sampling technique used is purposive sampling, which is sampling based on subjective assessment of research based on certain characteristics that are considered to have a relationship with population characteristics that have been known beforehand with certain considerations, namely UIN SU students who have studied the media. This study uses a Likert scale as a measurement scale statement of student perceptions. According to Sugiyono (2016) the Likert scale is used to measure the attitudes, opinions and perceptions of a person or group of people about social phenomena. The indicators are in the following table:

Table 1. Linked scale/opinion

\begin{tabular}{cc}
\hline Opinion & Skor \\
\hline Strongly disagree & 1 \\
Disagree & 2 \\
Agree & 3 \\
Strongly agree & 4 \\
\hline
\end{tabular}

Source: primer data.

\section{Validity Test}

Table 2. Validation test result

\begin{tabular}{lllll}
\hline $\mathbf{Q}$ & $\mathbf{N}$ & r-hitung & r-tabel & Validitas \\
\hline $\mathbf{1}$ & & 0.602 & 0.138 & Valid \\
$\mathbf{2}$ & 252 & 0.758 & 0.138 & Valid \\
$\mathbf{3}$ & & 0.679 & 0.138 & Valid \\
$\mathbf{4}$ & & 0.702 & 0.138 & Valid \\
\hline
\end{tabular}

Source: primer data

Validity determines which gauge increases to measure what was taken. Generated as by correlating between the scores obtained on each question item with an individual total score. Validity testing is done with the help of a computer using the SPSS program for Windows Version 26.0. In this study, validity testing was only carried out on 252 respondents. Decision making is based on the calculated value (Total Corrected Goods) Correlation)> $r$ table of 0.138. Based on Table 2. then it can be seen that all questions are for variables training material has a valid status, because the value is calculated (Corrected Item-Total Correlation) $>$ table of 0.138 .

\section{Reability Test}

Reliability test is performed on question items that are declared valid. Something variables are said to be reliable or reliable if the answer to the question is always consistent. The instrument reliability coefficient is intended to see the consistency of the answers statement items provided by the respondent The analysis tools using the split half method by correlating the total odd scores even opponent, then the reliability is calculated using the formula "Alpha Cronbach '. The calculation 
is done with the help of a computer program SPSS. As for The reliability for each variable results are presented in the following table 3 .

Tabel 3. Reliabilition tes result

\begin{tabular}{lllllll}
\hline $\mathbf{Q}$ & $\mathbf{N}$ & Variance & $\begin{array}{c}\boldsymbol{\Sigma} \\
\text { Variance }\end{array}$ & $\begin{array}{l}\text { Variance } \\
\text { total }\end{array}$ & r-ac & reliabilitas \\
\hline $\mathbf{1}$ & & 0.641 & & & & \\
$\mathbf{2}$ & 252 & 0.810 & 2.816 & 5.302 & 0.625 & Reliable \\
$\mathbf{3}$ & & 0.730 & & & & \\
$\mathbf{4}$ & & 0.634 & & & & \\
\hline
\end{tabular}

Sumber: Data primer

Table 3. shows that the Cronbach's Alpha value is on each dimension has a value > 0.6, then each can be concluded Question items from 4 dimensions are reliable.

\section{Respondent Identity}

Graph 1. Gender breakdown of respondents

\section{Persentage of Gender}

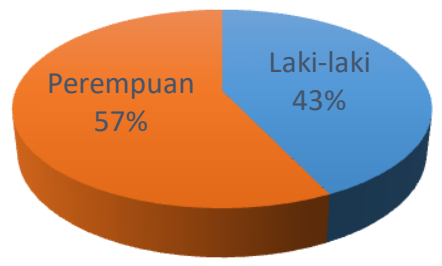

Graph 2: Average of Media use to obtain corona virus topic

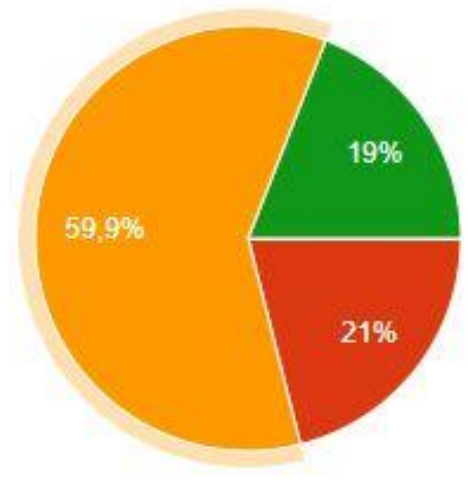

Surat Kabar

Media online berbasis web (contoh detik.com, Kompas.com, Okezone.com)

Media sosial (Instagram,

Facebook, Twitter)

Televisi

Radio

The average of media use for is shown that respondents indicated they had the most often is social media, followed by news website, an online newspaper website.Traditional news sources, television is the third most used news sources. This has also been proven by previous studies that young people prefer social media to get information than traditional media such as newspapers, television and radio. 
The second place is online news websites with 21 percent. Online news is trusted because it is considered to have credibility and is free from intervention.

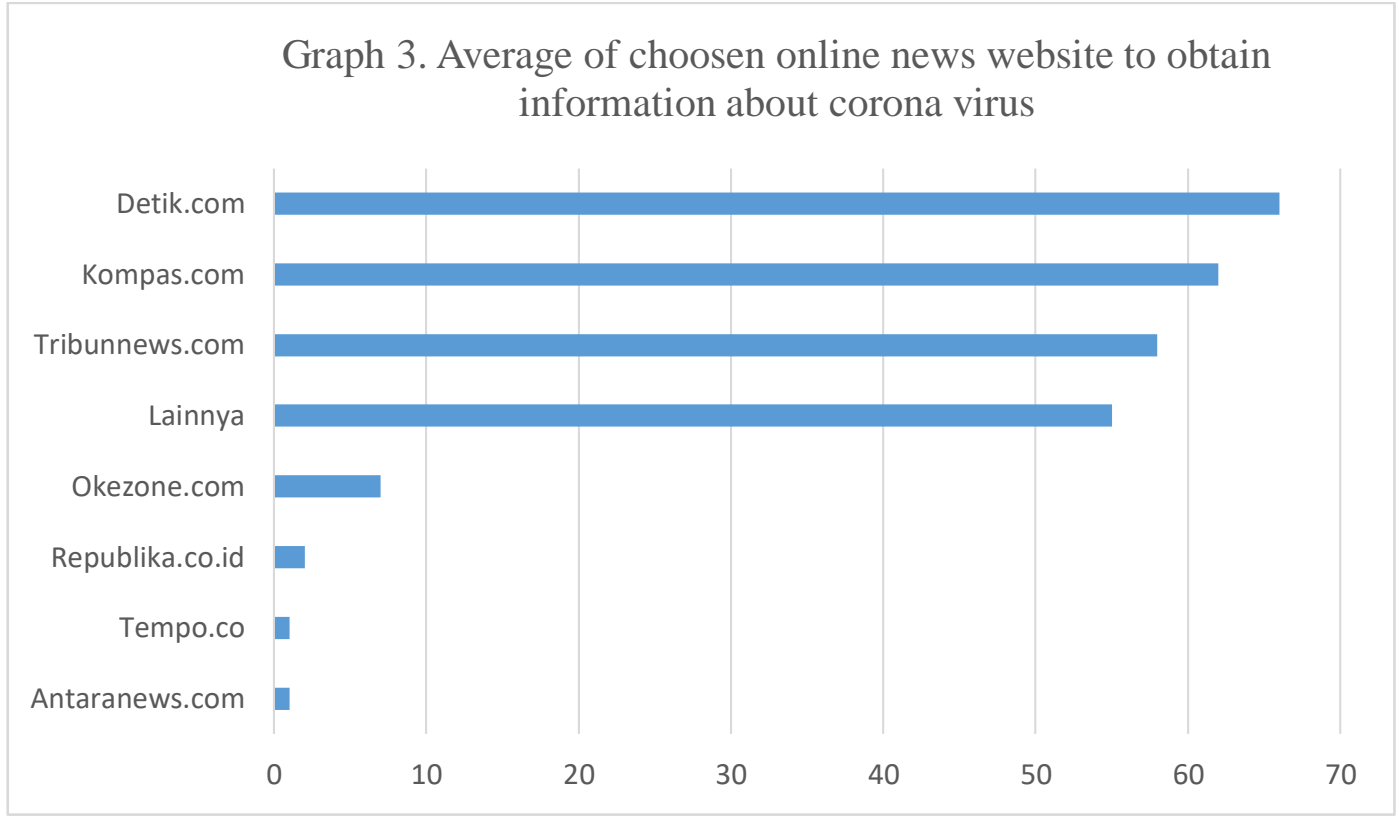

Source: primer data

Data from the media respondents indicated that the most choices were Detik.com, followed by Kompas.Com and Tribunnews.com. This is because the online news website is the national and most popular online news in Indonesia. This is consistent with the publication of Alexa Traffic Rank which places these media in an orderly position. ${ }^{18}$

Tabel 4. Choosen news website breakdown in association with the statement "news website is focus on Corona virus Topic"

\begin{tabular}{|c|c|c|c|c|c|c|}
\hline \multirow{2}{*}{\multicolumn{2}{|c|}{ Uraian }} & \multicolumn{4}{|c|}{ Selectivity of Topic } & \multirow[b]{2}{*}{ Total } \\
\hline & & $\begin{array}{l}\text { strongly } \\
\text { disagree }\end{array}$ & Disagree & Agree & strongly agree & \\
\hline \multirow{8}{*}{ News Website } & detik.com & $1,98 \%$ & $7,14 \%$ & $15,08 \%$ & $1,98 \%$ & $26,19 \%$ \\
\hline & kompas.com & $2,78 \%$ & $9,92 \%$ & $9,52 \%$ & $2,38 \%$ & $24,60 \%$ \\
\hline & tribunnews.com & $3,57 \%$ & $5,16 \%$ & $11,90 \%$ & $2,38 \%$ & $23,02 \%$ \\
\hline & republika.co.id & $0,00 \%$ & $0,40 \%$ & $0,00 \%$ & $0,40 \%$ & $0,79 \%$ \\
\hline & okezone.com & $0,40 \%$ & $0,79 \%$ & $1,19 \%$ & $0,40 \%$ & $2,78 \%$ \\
\hline & tempo.co & $0,00 \%$ & $0,40 \%$ & $0,00 \%$ & $0,00 \%$ & $0,40 \%$ \\
\hline & antaranews.com & $0,00 \%$ & $0,40 \%$ & $0,00 \%$ & $0,00 \%$ & $0,40 \%$ \\
\hline & lainnya & $2,38 \%$ & $10,71 \%$ & $7,94 \%$ & $0,79 \%$ & $21,83 \%$ \\
\hline \multicolumn{2}{|r|}{ Total } & $11,11 \%$ & $34,92 \%$ & $45,63 \%$ & $8,33 \%$ & $100,00 \%$ \\
\hline
\end{tabular}

Sumber: data primer

\footnotetext{
${ }^{18}$ https://www.it-jurnal.com/situs-berita-terpopuler-di-indonesia/
} 
Tabel 5. Tabel Chi-square Selectivity of Topic

\begin{tabular}{cc|c|c}
\hline & Value & Df & $\begin{array}{c}\text { Asymptotic } \\
\text { Significance (2-sided) }\end{array}$ \\
\hline Pearson Chi-Square & $24.895 \mathrm{a}$ & 21 & .252 \\
\hline Likelihood Ratio & 24.568 & 21 & .266 \\
\hline Linear-by-Linear Association & 4.239 & 1 & .040 \\
\hline N of Valid Cases & 252 & & \\
\hline r & &
\end{tabular}

a. 18 cells $(56.3 \%)$ have expected count less than 5 . The minimum expected count is .08 .

The data shows that most respondents agreed that the news website of their choice published a lot of information about the corona virus, which was a total of $45.63 \%$, but those who did not agree that the media of their choice focused on the corona virus topic was not much different by $34.92 \%$. Detik.com is the most online media choice of respondents who provide information about corona virus.

Tabel 6. Choosen News website in aasociation with statement "News media report the fact accurately about corona virus"

\begin{tabular}{|c|c|c|c|c|c|c|}
\hline \multirow{2}{*}{\multicolumn{2}{|c|}{ Uraian }} & \multicolumn{4}{|c|}{ Selectivity of Facts } & \multirow[b]{2}{*}{ Total } \\
\hline & & $\begin{array}{l}\text { strongly } \\
\text { disagree }\end{array}$ & Disagree & Agree & strongly agree & \\
\hline \multirow{8}{*}{ News Website } & detik.com & $3,17 \%$ & $9,92 \%$ & $9,92 \%$ & $3,17 \%$ & $26,19 \%$ \\
\hline & kompas.com & $2,78 \%$ & $9,13 \%$ & $9,52 \%$ & $3,17 \%$ & $24,60 \%$ \\
\hline & tribunnews.com & $3,57 \%$ & $8,33 \%$ & $6,35 \%$ & $4,76 \%$ & $23,02 \%$ \\
\hline & republika.co.id & $0,40 \%$ & $0,00 \%$ & $0,00 \%$ & $0,40 \%$ & $0,79 \%$ \\
\hline & okezone.com & $0,40 \%$ & $1,59 \%$ & $0,79 \%$ & $0,00 \%$ & $2,78 \%$ \\
\hline & tempo.co & $0,00 \%$ & $0,40 \%$ & $0,00 \%$ & $0,00 \%$ & $0,40 \%$ \\
\hline & antaranews.com & $0,00 \%$ & $0,40 \%$ & $0,00 \%$ & $0,00 \%$ & $0,40 \%$ \\
\hline & lainnya & $4,76 \%$ & $11,51 \%$ & $3,97 \%$ & $1,59 \%$ & $21,83 \%$ \\
\hline \multicolumn{2}{|c|}{ Total } & $15,08 \%$ & $41,27 \%$ & $30,56 \%$ & $13,10 \%$ & $100,00 \%$ \\
\hline
\end{tabular}

Sumber: data primer

Tabel 7. Chi-square table news media report the fact accurately

\begin{tabular}{lr|r|rr} 
& & & \multicolumn{2}{c}{$\begin{array}{c}\text { Asymptotic Significance (2- } \\
\text { sided) }\end{array}$} \\
\hline Pearson Chi-Square & $23.987^{\mathrm{a}}$ & df & 21 & .294 \\
\hline Likelihood Ratio & 25.444 & 21 & .228 \\
\hline Linear-by-Linear Association & 8.617 & 1 & .003 \\
\hline N of Valid Cases & 252 & & & \\
\hline
\end{tabular}

a.16 cells (50.0\%) have expected count less than 5 . The minimum expected count is .13 .

Most respondents said they did not agree that the online media of their choice contained the truth about the information conveyed by the media. Only 30.56 percent of respondents believe that the online media does deliver accurate news about the corona virus. This is interesting because it shows that respondents did not simply trust information especially about the corona virus even though the media was their choice. Even those who stated strongly disagree that online news website published the right facts about corona is also significant, which is as much as $13.10 \%$, slightly different from respondents who stated their dislike to the online media $15.08 \%$. This discovery is in line with the statement that media users consume media that they do not believe in the truth. This is because there are many 
studies that prove that young people more often use online news to get news because of the ease of access, not because they believe that online news contains true information. ${ }^{19}$

Tabel 8. Choosen news website breakdown in associaton with the statement "News website only report important facts about corona virus"

\begin{tabular}{|c|c|c|c|c|c|c|}
\hline \multirow{2}{*}{\multicolumn{2}{|c|}{ Uraian }} & \multicolumn{4}{|c|}{ Accuracy of Depictions } & \multirow[b]{2}{*}{ Total } \\
\hline & & $\begin{array}{l}\text { strongly } \\
\text { disagree }\end{array}$ & disagree & Agree & strongly agree & \\
\hline \multirow{8}{*}{ Media Online } & detik.com & $2,38 \%$ & $6,35 \%$ & $13,49 \%$ & $3,97 \%$ & $26,19 \%$ \\
\hline & kompas.com & $3,57 \%$ & $9,52 \%$ & $7,94 \%$ & $3,57 \%$ & $24,60 \%$ \\
\hline & tribunnews.com & $1,19 \%$ & $9,13 \%$ & $9,52 \%$ & $3,17 \%$ & $23,02 \%$ \\
\hline & republika.co.id & $0,40 \%$ & $0,00 \%$ & $0,00 \%$ & $0,40 \%$ & $0,79 \%$ \\
\hline & okezone.com & $0,40 \%$ & $0,79 \%$ & $1,19 \%$ & $0,40 \%$ & $2,78 \%$ \\
\hline & tempo.co & $0,00 \%$ & $0,00 \%$ & $0,40 \%$ & $0,00 \%$ & $0,40 \%$ \\
\hline & antaranews.com & $0,00 \%$ & $0,40 \%$ & $0,00 \%$ & $0,00 \%$ & $0,40 \%$ \\
\hline & lainnya & $0,40 \%$ & $8,73 \%$ & $7,54 \%$ & $5,16 \%$ & $21,83 \%$ \\
\hline \multicolumn{2}{|c|}{ Total } & $8,33 \%$ & $34,92 \%$ & $40,08 \%$ & $16,67 \%$ & $100,00 \%$ \\
\hline
\end{tabular}

Source: primer data

Tabel 9. Chi-square test accuracy depiction

\begin{tabular}{cc|c|c}
\hline & Value & df & $\begin{array}{c}\text { Asymptotic Significance (2- } \\
\text { side) }\end{array}$ \\
\hline Pearson Chi-Square & $26.047^{\mathrm{a}}$ & 21 & .205 \\
\hline Likelihood Ratio & 26.234 & 21 & .198 \\
\hline Linear-by-Linear Association & 1.236 & 1 & .266 \\
\hline N of Valid Cases & 252 & & \\
\hline
\end{tabular}

a. 18 cells (56.3\%) have expected count less than 5. The minimum expected count is .08 .

Responses to respondents' belief in selectivity of facts differ only slightly between respondents who do not believe and believe that online news websites only report important information about corona. Those who did not believe amounted to $34.92 \%$ meant they still found that the online news websites that they were consuming still spread news that was not considered important about the corona. Among the three online news website that are most often used by respondents. Kompas.com is considered the most widely published non-important news about corona which is only $7.2 \%$. This is quite surprising about the media choices most often used by Kompas.com to be in second position (Graph 3). This reinforces the fact that not all media users choose media that they often read because they believe that the media provides a lot of important information especially about the corona virus. Meanwhile $16.67 \%$ of respondents stated strongly disagree that online news websites only spread important information about the corona virus.

\footnotetext{
${ }^{19}$ Tsfati, Y. (2004). Exploring possible correlations of journalists' perceptions of audience trust. Journalism \& Mass Communications Quarterly, 81(2), 274-285.
} 
Tabel 10. Choosen news website breakdown in association with the statement "Journalist has good ability and skill in writing the news about corona virus"

\begin{tabular}{cccc|c|c|c}
\hline \multirow{2}{*}{ Uraian } & \multicolumn{4}{c|}{ Journalist Assesment } & \multirow{2}{*}{ Total } \\
\cline { 2 - 6 } & $\begin{array}{c}\text { strongly } \\
\text { disagree }\end{array}$ & disagree & agree & strongly agree & \\
\hline detik.com & $0,40 \%$ & $7,14 \%$ & $14,29 \%$ & $4,37 \%$ & $26,19 \%$ \\
\hline kompas.com & $0,00 \%$ & $3,57 \%$ & $14,29 \%$ & $6,75 \%$ & $24,60 \%$ \\
\hline tribunnews.com & $1,19 \%$ & $3,57 \%$ & $10,71 \%$ & $7,54 \%$ & $23,02 \%$ \\
\cline { 2 - 6 } News Website & republika.co.id & $0,00 \%$ & $0,40 \%$ & $0,00 \%$ & $0,40 \%$ & $0,79 \%$ \\
\cline { 2 - 6 } & okezone.com & $0,79 \%$ & $0,40 \%$ & $1,59 \%$ & $0,00 \%$ & $2,78 \%$ \\
\cline { 2 - 6 } & tempo.co & $0,00 \%$ & $0,40 \%$ & $0,00 \%$ & $0,00 \%$ & $0,40 \%$ \\
\hline antaranews.com & $0,00 \%$ & $0,00 \%$ & $0,40 \%$ & $0,00 \%$ & $0,40 \%$ \\
\hline lainnya & $1,98 \%$ & $5,95 \%$ & $8,33 \%$ & $5,56 \%$ & $21,83 \%$ \\
\hline Total & $4,37 \%$ & $21,43 \%$ & $49,60 \%$ & $24,60 \%$ & $100,00 \%$ \\
\hline
\end{tabular}

Sumber: data primer

Tabel 11. Chi-square tests Journalistic Assesment

\begin{tabular}{cc|c|c}
\hline & Value & df & $\begin{array}{c}\text { Asymptotic Significance (2- } \\
\text { sided) }\end{array}$ \\
\hline Pearson Chi-Square & $35.755^{\text {a }}$ & 21 & .023 \\
\hline Likelihood Ratio & 35.474 & 21 & .025 \\
\hline Linear-by-Linear Association & 2.510 & 1 & .113 \\
\hline N of Valid Cases & 252 & & \\
\hline
\end{tabular}

a. 20 cells (62.5\%) have expected count less than 5 . The minimum expected count is .04 .

It turns out that the majority of respondents believe that the journalists in the media they choose have a good ability in writing and reporting news that is as much as $49.60 \%$. This is because the online news website is a well-known online media and is a national media so respondents do not doubt their journalists' writing skills even though they do not believe that these media contain accurate facts. Only $21.3 \%$ of respondents disagreed that journalists lacked competence in writing. There are two online media that have the same percentage namely detik.com and tribunnews.com which is $14.29 \%$.

\section{CONCLUSION}

Based on data obtained by researchers in Islamic communication and broadcasting students of North Sumatra State Islamic University, most students chose social media such as Facebook and Instagram to get information about the corona virus, only a fraction of those who used online website media as their news source, followed by television. For online news websites, most students choose popular national media to get the latest information about the corona virus, such as Detik.com, Kompas.com and Tribunnews.com. Most of the students also believe that online news media journalists have good competency in writing news. But surprisingly some of them actually do not believe that the websites of their choice 
do not provide accurate facts about the corona virus. This shows that there is no significant relationship between the choice of media with the level of student confidence in the online news media in obtaining information about the corona virus.

\section{REFERENCE}

Cook, T,E., \& Gronke, W. 2001. The dimensions of institutional trust. Paper presented at the annual meeting of the Midwest Political Science Association, Chicago, IL. Retrieved April 5, 2011 from http://www.reed.edu/ gronkep/papers.html

Daugherty, T., and Hoffman, E. 2014. WOM and The Importance of Capturing Consumer Attention Within Social Media. Journal of Marketing Communication, 20(1-2), 82-102. doi:10.1080/13527266.2013.797764

Fadiyah Alaidrus. 2020. Kerja Berat Kemenkes Menangkal Hoaks Virus Corona. https://irto.id/kerja-berat-kemenkes-menangkal-hoaks-virus-corona-ev68.

Ilham Efendi. 2017. 7 Situs Berita Online Terpopuler di Indonesia. https://www.itjurnal.com/situs-berita-terpopuler-di-indonesia/

Keele, L. 2007. Social Capital and the Dynamics of Trust in Government. American Journal of Political Science, 51 (2), 241-254.

Kohring, M., and Matthes, J. 2007. Trust in News Media: Development and Validation of a Multidimensional Scale. Communication Research, 34(2), 231-252.

Krumsvik, A. H. 2018. Redefining User Involvement in Digital News Media. Journalism Practice, 12(1), 19-31. doi:10.1080/17512786.2017.1279025

Ksiazek, T. B., Malthouse, E. C., and Webster, J. G. 2010. News-seekers and Avoiders: Exploring Patterns of Total News Consumption Across Media and the Relationship to Civic Participation. Journal of Broadcasting \& Electronic Media, 54(4), 551-568. doi:10.1080/08838151.2010.519808

Lee, S. Hui. 2011. Does Trust Really Matter? A Quantitative Study of College Students' Trust and Use of News Media. Theses from the College of $\begin{array}{llll}\text { Journalism and Mass Communications. } & 15 .\end{array}$ https://digitalcommons.unl.edu/journalismdiss/15

Mayer, R.C., Davis, J.H., and Schoorman, F.D. 1995. An Integrative Model of Organicational Trust. Academy of management review, 20(3), 709-734

Metzger, M.J., Flanagin, A.J., and Zwarunb, L. 2003. College Student Web use, Perception of Information Credibility and Verification Behaviour. Computer and Education. $41: 271-290$.

Nurhajati, I., Sukandar, R., Oktaviani, R.C., dan Wijayanto, X. A. 2020. Perbincangan Isu Corona Covid 19 pada Media Daring dan Media Sosial.Lembaga Penelitian Pengabdian, Publikasi Masyarakat.P.14 
Youth's Trust in Online... Andini Nur Bahri

Prensky, M. 2001. Digital Natives, Digital Immigrants. On The Horizon, 9(5), pp. 16.

Sugiyono. 2016. Metode Penelitian Kuantitatif Kualitatif dan $R \& D$. Alfabeta. Jakarta.

Swanzen, R. 2018. Facing The Generation Chasm: The Parenting and Teaching of Generations $Y$ and $Z$. International Journal of Child, Youth and Family Studies, 9(2), 125-150. doi:10.18357/ijcyfs92201818216

Tamburaka. 2013. Literasi Media. Jakarta : PT Raja Grafindo Persada.

Tsfati, Y. 2004. Exploring Possible Correlations of Journalists' Perceptions of Audience Trust. Journalism \& Mass Communications Quarterly, 81(2), 274285.

Wilson, S., Leong, P., Nge, C., and Hong, N .M. 2011. Trust and Credibility of Urban Youth on Online News Media Malaysian. Journal of Communication Jilid 27(2): 97-120 